\title{
Investigating the effect of entrepreneurial intensity on creating competitiveness capabilities and export performance
}

\section{Investigar el efecto de la intensidad empresarial en la creación de capacidades de competitividad y el rendimiento de las exportaciones}

\author{
ROOSTAEE, Reza†, SHIRAZIAN, Zahra* and RAHIMI, Mohammad \\ Department of Management, Malayer Branch, Islamic Azad University, Malayer, Iran \\ ID $1^{\text {st }}$ Author: Reza, Roostaee / ORC ID: 0000-0002-1569-6691, Researcher ID Thomson: E-3339-2019 \\ ID $1^{\text {st }}$ Coauthor: Zahra, Shirazian / ORC ID: 0000-0003-2457-9216, Researcher ID Thomson: I-1315-2018 \\ ID $2^{\text {st }}$ Coauthor: Mohammad, Rahimi / ORC ID: 0000-0002-4339-5407, Researcher ID Thomson: H-3946-2018
}

DOI: 10.35429/EJM.2019.22.10.14.26

Received: December 30, 2018; Accepted: February 12, 2019

\begin{abstract}
The objective of this study was investigation of the entrepreneurial intensity and strategic orientation role in creating competitiveness capabilities and export performance. The present research is an applied and quantitative survey that was done in a Cross sectional method. The population of this study include 1900 staff of Ilam petrochemical company that a sample of 372 members of them was selected among them by simple-random method and without replacement. Data gathering tool in this research was standard questionnaire that its validity and reliability were evaluated and confirmed. In order to data analysis the structural equations based on the minor least squares was used and was performed by PLS smart software. The obtained results indicate that the entrepreneurial intensity has a significant effect on the strategic orientation, competitiveness capabilities and export performance. Also the finding confirm this fact that the strategic orientation has a significant effect on the competitiveness capabilities and export performance. Also they showed that the competitiveness capabilities has an significant effect on the export performance.
\end{abstract}

Entrepreneurial intensity, Strategic orientation, Competitiveness capabilities, Export performance

\begin{abstract}
Resumen
El objetivo de este estudio fue investigar la intensidad empresarial y el rol de orientación estratégica en la creación de capacidades de competitividad y el desempeño de las exportaciones. La presente investigación es una encuesta aplicada y cuantitativa que se realizó en un método de corte transversal. La población de este estudio incluye 1900 empleados de la compañía petroquímica Ilam, de los cuales una muestra de 372 miembros de ellos fue seleccionada entre ellos por un método aleatorio simple y sin reemplazo. La herramienta de recopilación de datos en esta investigación fue un cuestionario estándar que evaluó y confirmó su validez y confiabilidad. Para el análisis de los datos, se utilizaron las ecuaciones estructurales basadas en los mínimos cuadrados menores y se realizaron mediante el software inteligente PLS. Los resultados obtenidos indican que la intensidad empresarial tiene un efecto significativo en la orientación estratégica, las capacidades de competitividad y el desempeño de las exportaciones. También el hallazgo confirma este hecho de que la orientación estratégica tiene un efecto significativo en las capacidades de competitividad y el rendimiento de las exportaciones. También demostraron que las capacidades de competitividad tienen un efecto significativo en el desempeño de las exportaciones.
\end{abstract}

Intensidad empresarial, Orientación estratégica, Capacidades de competitividad, Desempeño exportador

Citación: ROOSTAEE, Reza, SHIRAZIAN, Zahra and RAHIMI, Mohammad. Investigating the effect of entrepreneurial intensity on creating competitiveness capabilities and export performance. ECORFAN Journal-Mexico. 2019, 10-22: 14-26.

\footnotetext{
* Correspondence to Author (zahra.shirazian@gmail.com)

$\dagger$ Researcher contributing first Author.
} 


\section{Introduction}

The rapid growth in the new technology, increasing demand of the customers, intensity of competition in the market and globalization are some of reasons that confirm this fact that "the market have changed significantly". The market globalization has caused more changes. Accordingly less number of the companies can distance from threats and use of opportunities. The companies interaction method in this market was appeared in different forms that one of useful cases of them in the international business is exports (Akbary. et $\mathrm{Al} ; 2015)$. An important factor in the export performance is entrepreneurial and it's intensity in the organization. Entrepreneurial and exports are two essential elements in the country's economic growth process through creating or development of business.

The entrepreneurial with creating and transmission of knowledge and increasing competitiveness and diversity help to economic growth. The exports also with development of internal industry, productivity and employment has a positive effect on the rate of the national reserves and prosperity, also from human capital and technology lead to learning.

The entrepreneurial and exports separately in the marketing theoretical bases, management and economy have been under attention and the academies have attend to the new investment based on exports in the international entrepreneurial in the past decade (Rastegar \& Shabani; 2016). On the other hand it should be mentioned that the exporter organizations success in the international market is not accidental. The competition in one hand and the constant changes on the other hand cause the organization face to complex conditions that need to long-term strategy and planning.

Accordingly one of the preliminaries of having a successful exports is having a longterm strategy and planning and the essentials of the correct strategy and planning is having its preliminaries such as correct strategic orientation. The strategic orientation is defined as a competitive action in the market (Mostalehet $\mathrm{Al} ; 2016)$. Accordingly the global competition and the customer's expectations increasing have led to this fact that the producer focus on the delivery speed and reliability and flexibility more than past (Nazemi \& Khavidar; 2010).
This case refer to the company competitiveness capabilities in the competition field. The abilities are some of actions that a company can do better than its rivals. In the field of the market oriented competitive strategy, the entrepreneurship is a determinant factor of the identified strategy. The organization entrepreneurship approach is an important factor in determination of its competition approach. The organizational entrepreneurship is the products development process or new markets.

The obtained evidences indicate that the entrepreneurial intensity can effect on the organizations performance. On the other hand the organization's strategic positioning in the market has an important role in its export performance. The strategic orientation is guide principles that have effect on the marketing and business strategy of the company.

They reflect the performed strategic instructions of a company that leads to correct behaviors for better performance (Theodosiou. et $\mathrm{Al} ; 2012)$. Strategic orientation is defined as the method of a company for accommodation with external environment (Madanglu et al; 2011). The strategic orientation of understanding the special management, preparations, tendencies, motivations and demands that guide the strategic planning and strategic development (Mostaleh. et al; 2016) and finally it should be mentioned that the success is not appeared in the performance unless with increasing and improving the competition capability of the organization.

\section{Literature review}

\section{Entrepreneurial intensity model}

Parakash et al (2015) in their study with positivism approach used of the measuring device for measuring the intensity of the entrepreneurship with three components of proactiveness, risk taking and innovativeness. This model is showed in the following figure:

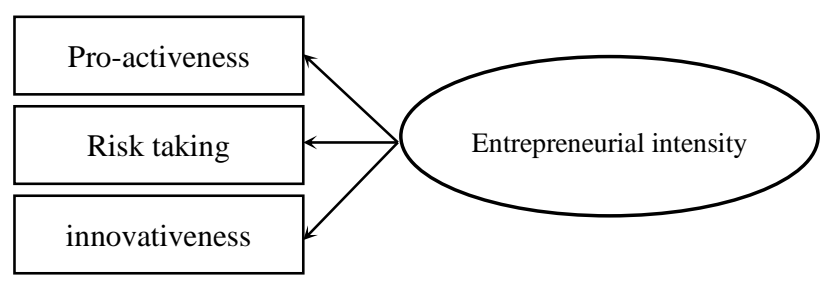

Figure 1 The entrepreneurial intensity model (Parkash et $\mathrm{Al} ; 2015)$

ROOSTAEE, Reza, SHIRAZIAN, Zahra and RAHIMI, Mohammad. Investigating the effect of entrepreneurial intensity on creating competitiveness capabilities and export performance. ECORFAN Journal-Mexico. 2019. 
Pro-activeness: include significant perseverance, compatibility and capability in looking the future (Parkash et al; 2015).

Risk taking: include tendency to significant tendency to source assignment to the opportunities when they may face to failure (Parkash. et al; 2015).

Innovativeness: refers to innovative, unusual or new solutions for problems and needs (Parkash. et al; 2015).

Organization strategic orientation: means the organization competition culture or the method of business management in the competitive market (Brower \& Rowe; 2017).

\section{Organization strategic orientation model}

Brower \& Rowe (2017) used of conceptual device for measuring the organization strategic orientation that has four components of customer trends, competitor trends, crossfunctional co-operation and shareholder trends. This model is showed in the following figure:

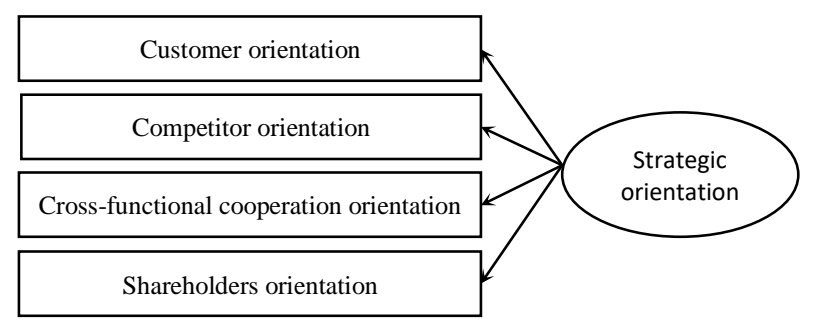

Figure 2 Organization strategic orientation model (Brower \& Rowe 2017)

Customer orientation: explains the culture of company in which the customers are regarded as a prefered actors or not (Brower \& Rowe; 2017). Competitor orientation: refer to this fact that to what extent a company focus on weaknesses and strengths and threats of its main competitor considering the opportunities, threats, weaknesses and strengths (Brower \& Rowe ; 2017).

Cross-functional cooperation orientation: refers to sharing and consent culture of working to each other that is a basis of inter sectional interaction activities and focus on the effectiveness and efficiency that facilities the relationship between different functions of the organization (Brower \& Rowe; 2017).

\section{Competitiveness capabilities model}

Sardana. et al in their study used a model with two components of delivery capability and cost control capability for measuring the concept of competitiveness capabilities. This model is showed in following figure:

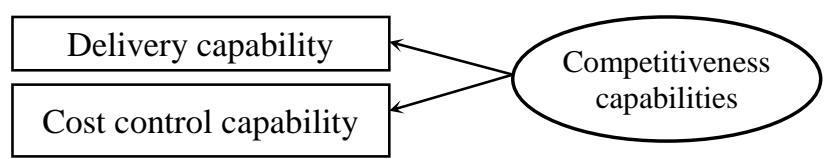

Figure 3 Competitiveness capability model (Sardana. et $\mathrm{al} ; 2016)$

Cost control capability: explains the existence of the workers costs unit and product production entire costs in the organization (Sardana et al ; 2016).

\section{Export performance model}

Is a variable that inherently is related to the export performance. The export performance is identified as a limitation that in which the agency purposes (such as strategic and economic purposes) for exporting a product is fulfilled through planning and performing the export marketing strategies. (Moshabaki \& khademi; 2012), Ouva. et al (2015) in their study consider the export performance as a case that have three dimensions of financial performance, strategic performance and acceptable performance that are showed it the following figure:

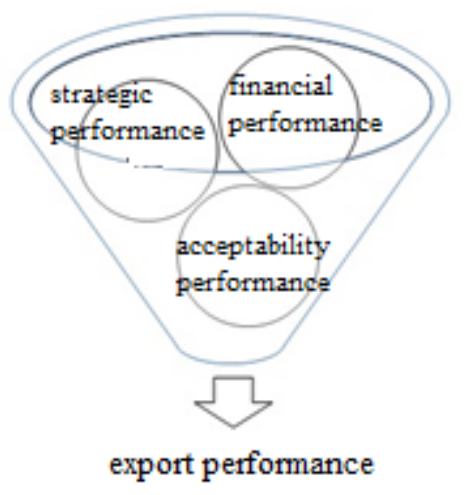

Figure 4 Export performance model ( Oura. et al ;2015)

Financial performance: refers to the growth rate of the product- market exports investment and the rate of profitability and it's sale volume (Oura. et al; 2015). Strategic performance: explains the role of product exports investigation- market in improving and strengthening the competitive and strategic situation and achievement of an organization to the export objectives (Oura. et al; 2015). 
Acceptable performance: controls the acceptability, success and accommodation of market- product export investment with expectations of the organization (Oura et al; 2015).

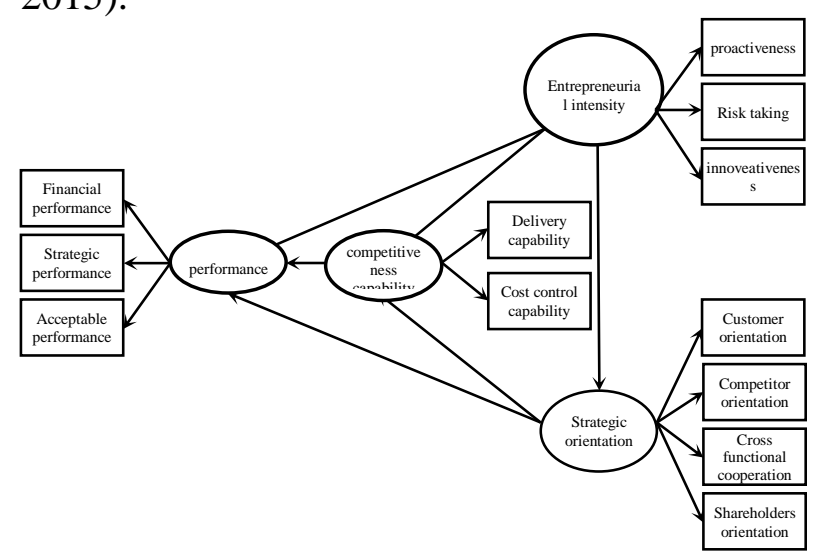

Figure 5 Research performance model: (sources: parkas et al, 2015; Brower \& Rowe, 2017; Sardana et al, 2016; Oura et al, 2015)

\section{Research Hypothesis}

The first hypothesis: Entrepreneurial intensity has a significant effect on the export performance.

Sub hypothesis:

- $\quad$ Sub hypothesis 1-1: Pro- activeness has a significant effect on the export performance.

- Hypothesis 2-1: Risk taking has a significant effect on the export performance.

- Sub hypothesis 3-1: Innovativeness has a significant effect on the export performance.

The second hypothesis: The entrepreneurial intensity has a significant effect on the strategic orientation.

Sub hypothesis:

- Sub hypothesis 1-2: Pro-activeness has a significant effect on the strategic orientation.

- Sub hypothesis 2-2: Risk taking has a significant effect on the strategic orientation.

- $\quad$ Sub hypothesis 3-2: Innovativeness has a significant effect on the strategic orientation.
The third hypothesis: The entrepreneurial intensity has a significant effect on the competitiveness capabilities.

Sub hypothesis:

- Sub hypothesis 1-3: Pro-activeness has a significant effect on the competitiveness capabilities.

- Sub hypothesis 2-3: Risk taking has a significant effect on the competitiveness capabilities.

- $\quad$ Sub hypothesis 3-3: Innovativeness has a significant effect on the competitiveness capabilities.

The forth hypothesis: Strategic orientation has a significant effect on the competitiveness capabilities.

Sub hypothesis:

Sub hypothesis 1-4: The customer trends has a significant effect on the competitiveness capabilities.

- $\quad$ Sub hypothesis 2-4: Competitor trends has a significant effect on the competitiveness capabilities.

- Sub hypothesis 3-4: The cross- functional co-operation trends has a significant effect on the competitiveness capabilities.

- Sub hypothesis 4-4: The shareholders trends has a significant effect on the competitiveness capabilities.

The fifth hypothesis: Strategic orientation has a significant effect on the export performance.

- Sub hypothesis: Customer's orientation has a significant effect on the export performance.

- Sub hypothesis 2-5: Competitor orientation has a significant effect on the export performance.

- Sub hypothesis 3-5: Cross- functional cooperation trends has a significant effect on the export performance.

- Sub hypothesis 4-5: Shareholders trends has a significant effect on the export performance.

The sixth hypothesis: The competitiveness capabilities has a significant effect on the export performance. 
Sub hypotheses:

- Sub hypothesis 1-6: Delivery capability has a significant effect on the export performance.

- Sub hypothesis 2-6: Cost control capability has a significant effect on the export performance.

\section{Literature Review}

Kadivar (2017) performed his research under the title of the effect of the trend to entrepreneurship on the export performance intensity with emphasize on the organizational variables. The results of this study indicate that the entrepreneurship variable has effect on the innovation and learning variables. Also there is a relationship between the innovation variables and uncertainty with export intensity and there is not a significant relationship between the organizational learning variable and export intensity.

Aslanlou \& Khodami (2018) in a study under the title of the effect of knowledge inertia and the entrepreneurship intensity on the brand performance tried to investigate the effective inter organizational and extra organization factors on the organization brand with a combined approach. The obtained results indicate that the organizational innovation and organizational learnability in three market oriented dimensions of market -based learning, Relationship based learning and internal focused learning played mediation role in the relation making between knowledge inertia and entrepreneurship intensity with brand performance.

Nazemi \& Kharidar (2010) performed a study under the title of the effect of integrated supply chain on the competitive capabilities in food and beverage industries of Mashhad city. The obtained results of this study indicate that the internal integration and external integration have a positive effect on the improving of the competitive capabilities of company.

Akbari et al (2015) performed a study under the title of (investigating the effect of entrepreneurship trend and innovation ambidexterity on the export performance of the new products with decreasing the intensity of the product innovation in automotive industry.
The obtained results indicate that tendency to entrepreneurship has a significant effect on the innovation ambidexterity and export performance of the new products.

Mosleh. et al (2016) performed a study under the title of the effect of the strategic orientation dimension on the export performance of export companies of Booshehr province. The obtained results indicate that the aggressive strategy has not a significant effect on the export performance and futuristic strategy, proactiveness and risk taking have a positive and significant on the export performance.

Sedigh. et al (2016) performed another study under the title of determination of the effect between the strategic orientation with organizational performance. The obtained results indicate that the business strategy has a significant role in the organizational performance and over activation foresight, analytical and risk fullness and defensive dimensions have a positive and significant relationship with organizational performance.

Mosleh. et al (2016) performed a study under the title of the effect of strategic orientation dimensions on the export performance of the export companies of Booshehr province. The obtained results indicate that the aggressive strategy has not a significant effect on the export performance and futuristic strategy, pro-activeness and risk taking have a positive and significant effect on the export performance.

Hajipour. et al (2015) performed a study under the title of the effect of strategic orientation and marketing capabilities on the export performance. The obtained results of this study indicate that the marketing capabilities have a significant effect on the export performance.

Customer's trends, competitors trends and cost trends have a significant effect on the marketing capabilities while the innovation trends has not a significant effect on the marketing capabilities. On the other hand customer's trends have a significant and positive effect on the export performance while the competitor trends and innovation trends have not any effect on the export performance. 
Zarei Matin. et al (2010) performed a study under the title of investigating the relationship between the strategic orientation of a company with organizational performance by means of balanced scorecard approach. The obtained results of this study indicated that the business strategy has a significant effect on the organizational performance and the over activation, foresight, analytical and risk fullness dimensions have a positive and significant relationship with organizational performance.

Asiaban Rezaei (2010) performed their research under the title of the investigating of the strategic orientation effect on the new product development (evidences of the accepted companies in the Tehran stock exchange). The obtained results of this study indicate that the strategic orientation (market orientation dimension) has a significant and direct and indirect effect on the three dimensions of strategic orientation market-based, learningbased and entrepreneurship based on the new product development. Also the significant effect of processing mechanisms variables as a mediator variables was confirmed.

Brower \& Rowe (2017) performed a study under the title of "where the eyes see, the body goes, understanding strategic orientation on the social performance". The obtained results indicated that the companies with stronger strategies orientation have better social performance in customer orientation.

Mu. et al (2016) in a study under the title of strategy orientation and product development performance, investigated the role of networking capacities and networking compatibilities, and companies capabilities effect for relationship with foreigner partners and manager's ability for new product development project for the network with shareholders of company. Babe can see their the Environmental dynamism as the control variable.

De Lima Rua \& Silvo franca (2016) performed a study under the title of the relationship of innovativeness orientation with exports performance. The obtained results indicated that the innovativeness orientation improves the exports performance.
Roso (2010) performed his study under the title of entrepreneurial orientation and export performance. The obtained results indicate that the innovativeness orientation has a positive and significant effect on the export performance.

Theodosius. et al (2012) in his study under the title of investigating 316 Bank branch presented a model that links the strategic orientation with organizational performance through marketing mediator varietal effect. They found that the market disturbance and competition intensity and not having focuses in dimension making have a significant effect on their prioritizing the managerial strategic. In addition, competitor orientation and Innovation orientation help to development of the marketing and in turn the marketing has an effect on the company performance.

Ken. et al (2012) found that the strategic orientation has a significant effect on the product innovation. According to this study a conceptual framework was presented for understanding the relationships between their products innovation and market orientation, competitor orientation and customer orientation and strategic flexibility mediator variable. The basic concept of this model is that the companies considering the customers' needs should have their competitors technologic orientations that has effect on the planning, developing and commercialism the better and new products and obtaining the innovation advantage.

Attin dog and Ziher (2012) started special research for investigation on the family companies performance of Turkey. Six dimensions of this investigation are market, innovation, relationships, customer, training and entrepreneurship. For comparing it with today conditions and scientific power of the this study three dimensions of relationships, customer and training were omitted. The obtained results indicate that innovation orientation leads to obtaining competitive advantage.

Mury (2012) in his studies under the title of organizational innovation and the role of the strategic orientation and environment evalution has this reasoning that there is a direct relationship between environmental evalution and aggressive strategy and analytical strategy that leads to creating innovation in the organization. 


\section{Research Methodology}

The present study is an applied research from objective point of view, quantitative from data kind point of view, cross sectional from research performance time point of view. Also the present research is a descriptive- survey from performance strategy point of view. The population of this study include 1990 staff of petrochemical company that 372 members of them were selected by convenience sampling. Data gathering tool of this research was questionnaire of Parkas. et al (2015) entrepreneurial intensity standard questionnaire. Brower \& Rowe (2017) organization strategic orientation, Sardana et al (2016) competitiveness capabilities and Oura. et al (2015) export performance questionnaires were used.

In order to evaluation of reliability of the questionnaire the Cronbach's Alpha coefficient and for evaluation of its validity the (Waltz \& Bausell) content was used. The rates of their CVI reliability and validity are presented in the following table:

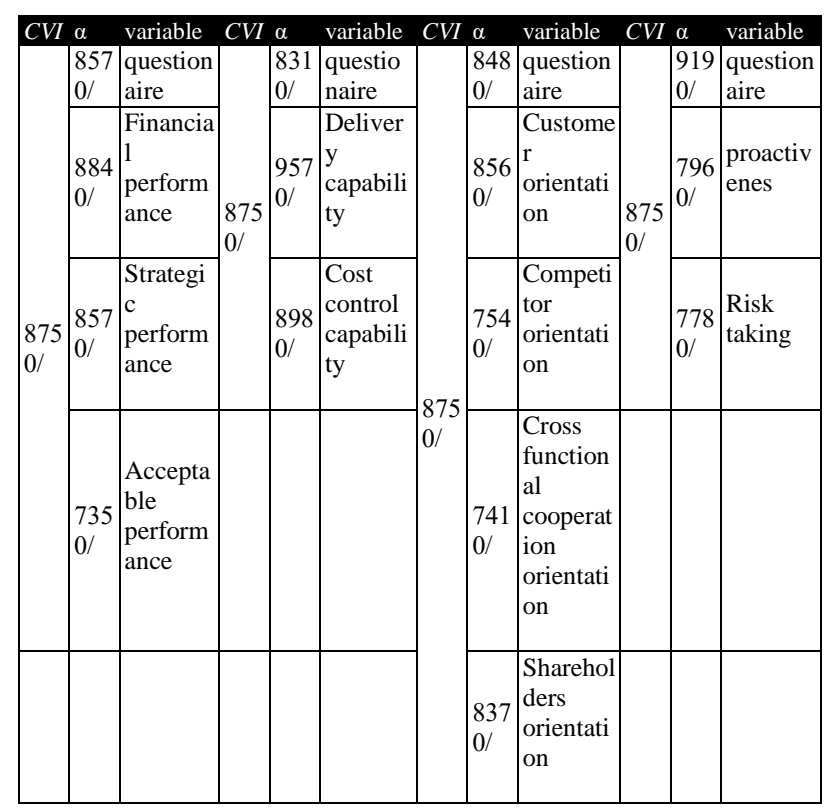

Table 1 The rates of Cronbach's Alpha of the research variables

As you can see in the above table the rates of Cronbach's Alpha of all of the components is more than the recommended rate of $0 / 7$, thus the research questionnaires have acceptable reliability. Also their validity rates are in a level more than $79 \%$, therefore it can be said that the research questionnaires have suitable validity.

\section{Research results}

In order to estimation of the main hypothesis, PLS smart software was used. The following graph shows the research estimated functional model:

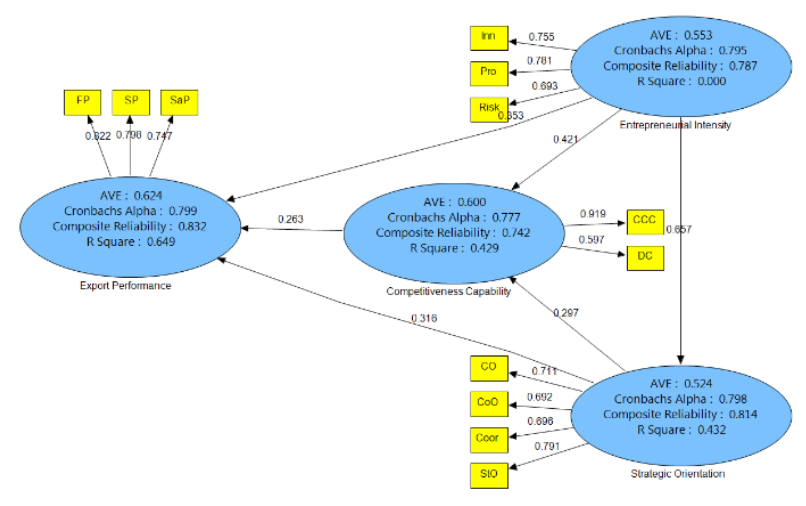

Graph 6 Estimation of the path coefficients for the mains research hypothesis

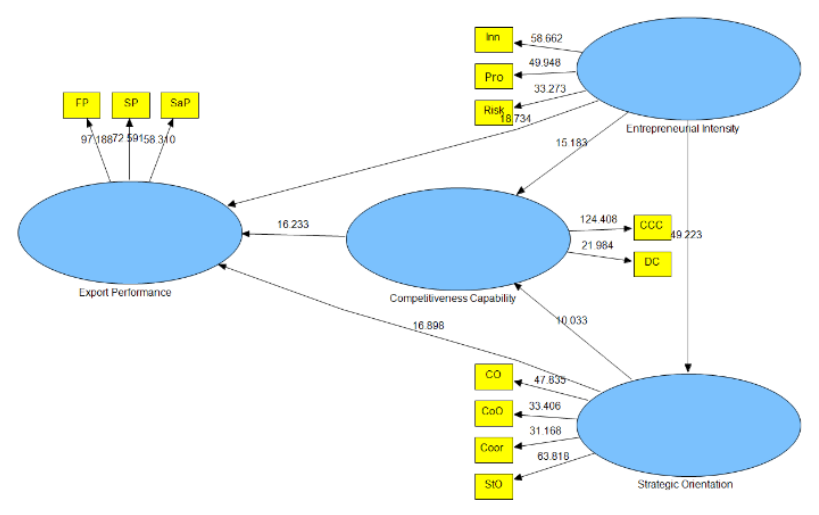

Graph 7 Estimation of the rates of T-values of the mains research hypothesis

Above figures show the path coefficients and $\mathrm{T}$-values between the research variables path coefficients are Beta standard rates that are showed in the following table.

\begin{tabular}{|c|c|c|c|c|c|c|}
\hline result & $t$-value & $\begin{array}{l}\text { Total } \\
\text { effect }\end{array}$ & $\begin{array}{l}\text { Indiret } \\
\text { effect }\end{array}$ & $\begin{array}{l}\text { Dirrect } \\
\text { effect }\end{array}$ & communication & Hypothesis \\
\hline confirm & $18 / 734$ & $0 / 722$ & $369 / 0$ & $0 / 353$ & $\begin{array}{l}\text { entrepreneurial } \\
\text { intensity } \leftarrow \text { export } \\
\text { performance }\end{array}$ & 1 \\
\hline confirm & $49 / 223$ & $0 / 657$ & --- & $0 / 657$ & $\begin{array}{l}\text { entrepreneurial } \\
\text { intensity } \\
\text { strategic orientation }\end{array}$ & 2 \\
\hline confirm & $15 / 183$ & $0 / 616$ & $195 / 0$ & $0 / 421$ & $\begin{array}{l}\text { entrepreneurial } \\
\text { intensity } \leftarrow \text { export } \\
\text { performance }\end{array}$ & 3 \\
\hline confirm & $10 / 033$ & $0 / 297$ & -- & $0 / 297$ & $\begin{array}{l}\text { strategic orientation } \\
\leftarrow \text { export } \\
\text { performance }\end{array}$ & 4 \\
\hline confirm & $16 / 898$ & $0 / 394$ & $078 / 0$ & $0 / 316$ & $\begin{array}{l}\text { strategic orientation } \\
\leftarrow \text { export } \\
\text { performance }\end{array}$ & 5 \\
\hline confirm & $16 / 233$ & $0 / 263$ & -- & $0 / 263$ & $\begin{array}{l}\text { export performance } \\
\leftarrow \text { export } \\
\text { performance }\end{array}$ & 6 \\
\hline
\end{tabular}

Table 2 Tvalue rates and path coefficients of structural path model for main hypothesis 
As you can see the entrepreneurial intensity and strategic orientation have a positive and significant effect on the export performance. Also the variable of entrepreneurial intensity has a significant effect on the strategic orientation. Also it can be seen that the strategic orientation has a significant effect on the competitiveness capabilities but the obtained results indicate that the competitiveness capabilities has a significant effect on the export performance. Accordingly it can be said that any evidence for rejecting the main hypothesis was not observed.

It should be mentioned that, because in the present study the model was estimated with confidence of $95 \%$ and error $5 \%$ for confirming a hypothesis in confidence level of $95 \%$, the rate of least T-statistics should be equal to 1/96 (Azar et al, 2010; 126). Since for confirming a hypothesis is longer than the supposed rate of $1 / 96$ in confidence level of $95 \%$ and error level of $0 / 05$, they are acceptable. In the structural path modeling after investigation and testing the hypotheses, the estimated models quality indices should be estimated. In the structural path modeling there are three categories of goodness indices, the internal models goodness indices and whole model goodness indices. The following table shows these indices:

\begin{tabular}{|c|c|c|c|c|c|c|c|c|}
\hline \multicolumn{3}{|c|}{$\begin{array}{l}\text { Model quality } \\
\text { indices }\end{array}$} & \multicolumn{2}{|c|}{$\begin{array}{l}\text { Internal } \\
\text { model } \\
\text { indices }\end{array}$} & \multicolumn{3}{|c|}{$\begin{array}{l}\text { External model } \\
\text { indices }\end{array}$} & \multirow[t]{2}{*}{ variables } \\
\hline GOF & Red & Com & ${ }^{2} Q$ & $r^{2}$ & $A V E$ & $\rho$ & $\alpha$ & \\
\hline \multirow{4}{*}{$0 / 53$} & $0 / 201$ & $0 / 6$ & $0 / 248$ & $0 / 429$ & $0 / 6$ & $0 / 741$ & $0 / 776$ & $\begin{array}{l}\text { Competitiveness } \\
\text { capability }\end{array}$ \\
\hline & --- & $0 / 55$ & $0 / 581$ & --- & $0 / 55$ & $0 / 787$ & $0 / 795$ & $\begin{array}{l}\text { entrepreneurial } \\
\text { intensity }\end{array}$ \\
\hline & $0 / 174$ & $0 / 62$ & $0 / 389$ & $0 / 649$ & $0 / 62$ & $0 / 832$ & $0 / 798$ & $\begin{array}{l}\text { entrepreneurial } \\
\text { intensity }\end{array}$ \\
\hline & $0 / 223$ & $0 / 52$ & $0 / 206$ & $0 / 432$ & $0 / 52$ & $0 / 814$ & $0 / 797$ & $\begin{array}{l}\text { strategic } \\
\text { orientation }\end{array}$ \\
\hline
\end{tabular}

Table 3 Investigation of the internal, external and whole models indices and all of the research hypotheses

As you can see the rates of Cronbach's Alpha and composed reliability is more than the supposed rate of $0 / 5$. Therefore the external models have suitable goodness. $\mathrm{r} 2$ index also show that the predictor variables could predict the dependent variables, because the Q2 index is bigger than zero, it can be said that there is a predictor relationship. Also the shared index is more than the supposed rate of $0 / 5$ and the redundancy rate is not zero. This fact indicates the goodness of research model for the main hypotheses. GOF index shows that this model is predictable to $53 \%$.
A- testing the first sub hypothesis:

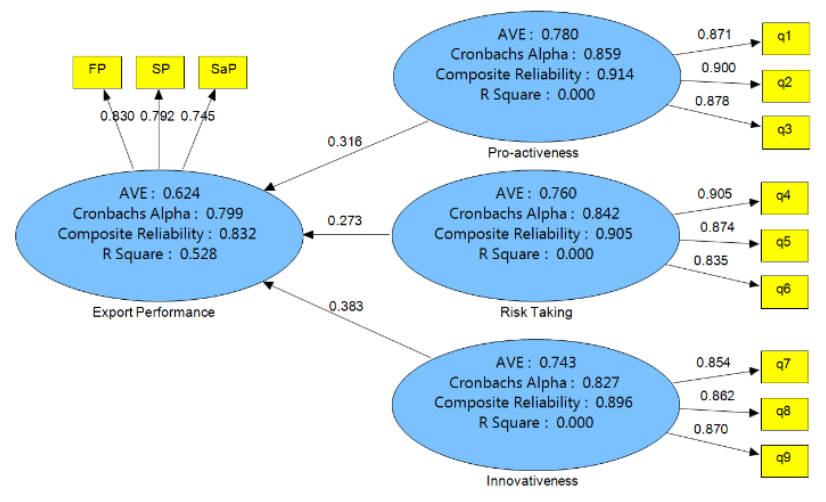

Graph 8 Estimation of the path coefficients for the first sub hypothesis

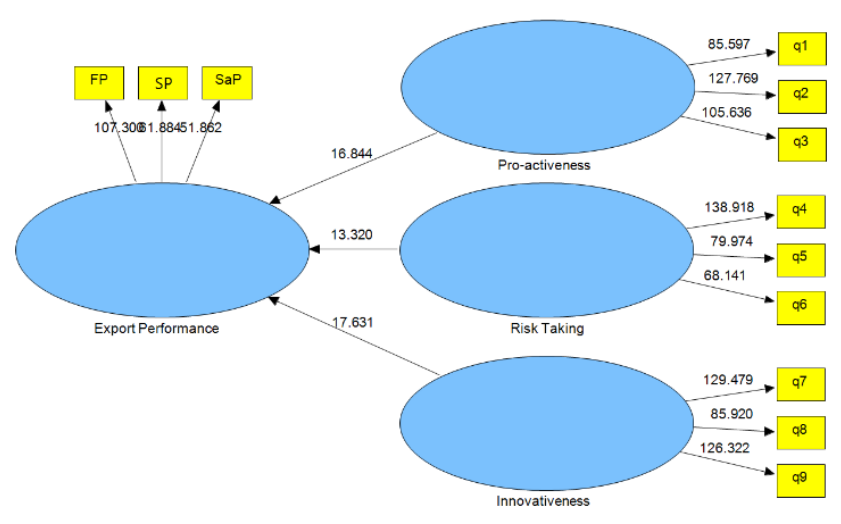

Graph 9 Estimation of T-values of the first sub hypothesis

Above figure show path coefficients and $\mathrm{T}$-values between the variables of this research. Path coefficients are defined as Beta standard rates. These rates are showed in the following table.

\begin{tabular}{|l|l|l|l|l|l|l|}
\hline Result & $\begin{array}{l}T- \\
\text { value }\end{array}$ & \multicolumn{2}{l|}{$\begin{array}{l}\text { Total Indiret } \\
\text { effect effect }\end{array}$} & $\begin{array}{l}\text { Dirrect } \\
\text { effect }\end{array}$ & \multicolumn{2}{l|}{ Communication Hypothesis } \\
\hline Confirm & $16 / 844$ & $0 / 316$ & --- & $0 / 316$ & $\begin{array}{l}\text { Proactiveness } \\
\text { Łexport } \\
\text { performance }\end{array}$ & $1-1$ \\
\hline Confirm & $13 / 320$ & $0 / 273$ & --- & $0 / 273$ & $\begin{array}{l}\text { Risk taking } \\
\text { export } \\
\text { performance }\end{array}$ & $2-1$ \\
\hline Confirm & $17 / 631$ & $0 / 383$ & --- & $0 / 383$ & $\begin{array}{l}\text { Innovativeness } \\
\text { export } \\
\text { performance }\end{array}$ & $3-1$ \\
\hline
\end{tabular}

Table 4 T-value rates and path coefficients of research structural path model for the first sub hypothesis

As you can see the components of entrepreneurial intensity such as pro-activeness riskfulness and innovation have positive and significant effect on export performance. It should be mentioned that since in the present research the model has been estimated with confidence level of $95 \%$ an error level of $5 \%$, thus for confirmation of a hypothesis in confidence level of $95 \%$. 
Least rate of t-statistics equals to $1 / 96$ (Azar. et al, 2010: 126), since t-value for the first sub hypothesis bigger than the supposed value of 1/96 in confidence level of 0/95 and error of 0/05 they are acceptable.

B- Testing the second sub hypothesis:

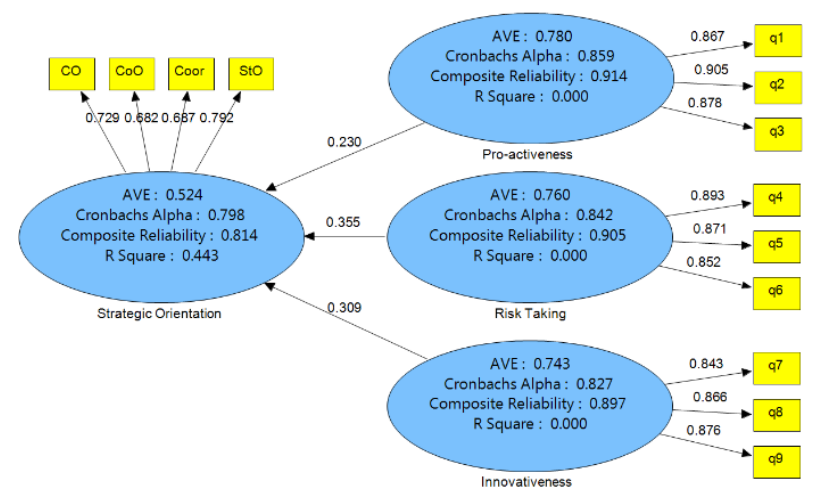

Graph 10 Estimation of path coefficient for the second sub hypothesis

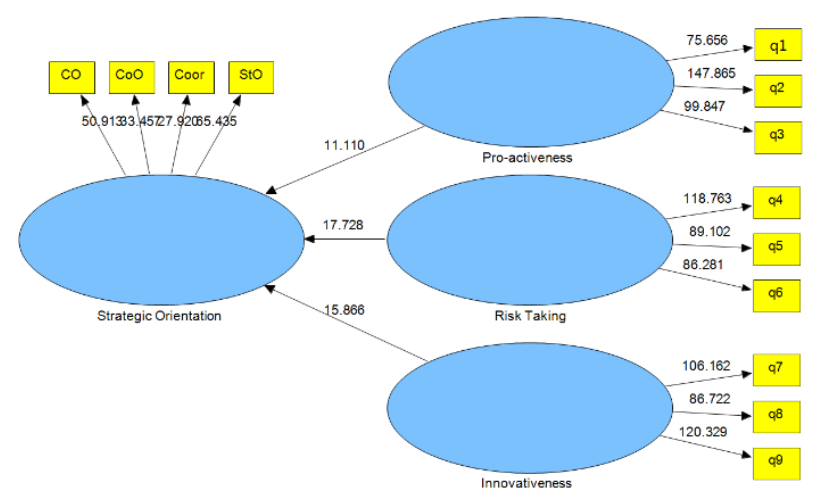

Graph 11 Estimation of t-values of the second sub hypothesis

Above figure shows path coefficients and tvalues between the research variables. Path coefficients are defined as Beta standard rates that are showed in the following table.

\begin{tabular}{|l|l|l|l|l|l|l|}
\hline Result & \multicolumn{2}{|c|}{$t$-value Total Indiret } \\
effect & \multicolumn{2}{|l|}{$\begin{array}{l}\text { Dirfect } \\
\text { effect }\end{array}$} \\
\hline confirm & $11 / 110$ & $0 / 230$ & --- & $0 / 230$ & $\begin{array}{l}\text { Strategic } \\
\text { orientation } \leftarrow \\
\text { proactiveness }\end{array}$ & $1-2$ \\
\hline confirm & $17 / 728$ & $0 / 355$ & --- & $0 / 355$ & $\begin{array}{l}\text { Risk taking } \leftarrow \\
\text { strategic } \\
\text { orientation }\end{array}$ & $2-2$ \\
\hline confirm & $15 / 866$ & $0 / 309$ & --- & $0 / 309$ & $\begin{array}{l}\text { innovativeness } \\
\text { strategic } \\
\text { orientation }\end{array}$ & $3-2$ \\
\hline
\end{tabular}

Table $5 \mathrm{t}$-value rates and path coefficients of the research structural path model for the second sub hypothesis

As you can see the entrepreneurial intensity components such as pro activeness, risk fullness and innovation have positive and significant effect on the strategic orientation.
Accordingly it can be said that any evidence of rejection of the second sub hypothesis was not observed. Since, t-value of the second sub hypothesis is bigger than the supposed value of 1/96 in the confidence level of $95 \%$ and error of $0 / 05$ it is acceptable.

C- Testing the third sub hypothesis:

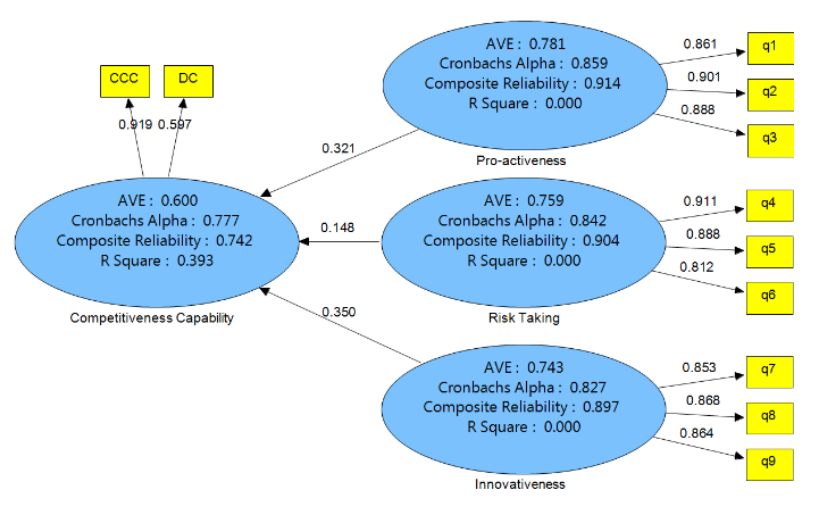

Graph 12 Estimation of path coefficients for the third sub hypothesis

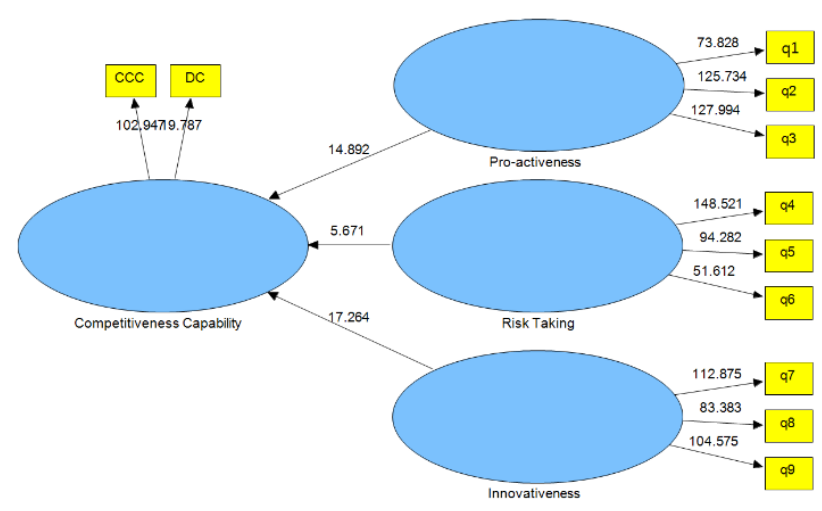

Graph 13 Estimation of $t$-values of the third sub hypothesis of research

Above figure indicates path coefficients and $t$-values between the research variables. Path coefficients are defined as Beta standard values that are presented in the following table.

\begin{tabular}{|l|l|l|l|l|l|l|}
\hline \multicolumn{2}{|c|}{ Result $t$-value } & \multicolumn{3}{|l|}{ Total Indiret Dirrect Communication } \\
effect effect & Hypothesis \\
\hline confirm & $14 / 882$ & $0 / 321$ & --- & $0 / 321$ & $\begin{array}{l}\text { competitiveness } \\
\text { capabilities } \leftarrow \\
\text { proactiveness }\end{array}$ & $1-3$ \\
\hline confirm & $5 / 671$ & $0 / 148$ & --- & $0 / 148$ & $\begin{array}{l}\text { Risk taking } \leftarrow \\
\text { competitiveness } \\
\text { capabilities }\end{array}$ & $2-3$ \\
\hline confirm & $17 / 264$ & $0 / 350$ & --- & $0 / 350$ & $\begin{array}{l}\text { innovativeness } \\
\text { competitiveness } \\
\text { capabilities }\end{array}$ & $3-3$ \\
\hline
\end{tabular}

Table $6 \mathrm{t}$-value rates and path coefficients of the structural path model for the second sub hypothesis

ROOSTAEE, Reza, SHIRAZIAN, Zahra and RAHIMI, Mohammad. Investigating the effect of entrepreneurial intensity on creating competitiveness capabilities and export performance. ECORFAN Journal-Mexico. 2019. 
As you can see the entrepreneurial intensity components such as pro activeness, riskfulness and innovation have positive and significant effect on the competitiveness capabilities. Accordingly it can be said that there are not any evidence of rejecting the third sub hypothesis. Since t-value for the third sub hypothesis is bigger than suppose the value of $1 / 96$ in confidence level of $0 / 95$ and error level of $0 / 05$. Thus this is acceptable.

D- Testing the forth sub hypothesis:

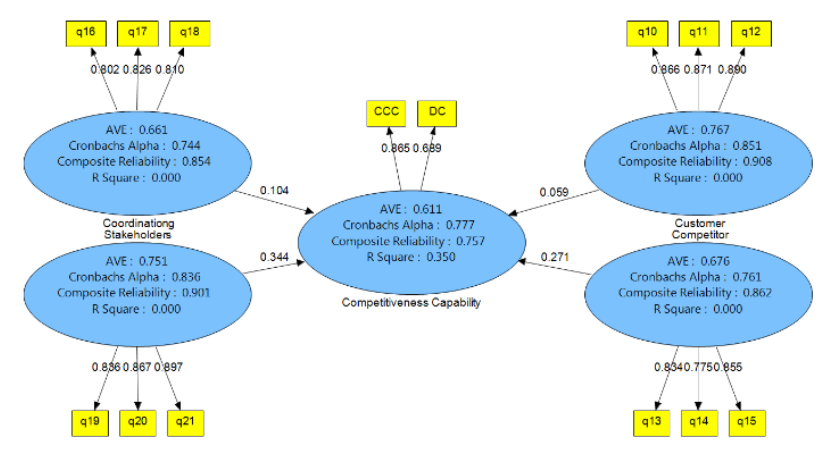

Graph 14 Estimation of the path coefficient for the forth sub hypothesis

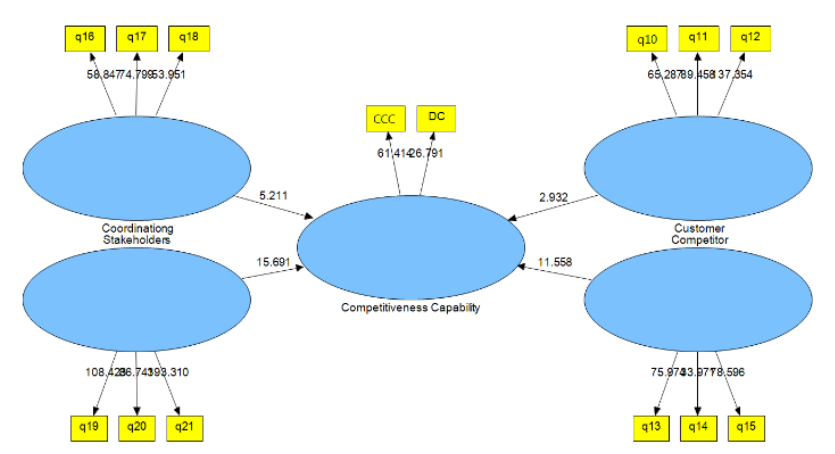

Graph 15 Estimation of t-values of the forth sub hypothesis

Above figure presents path coefficients and $t$-value between the research variables. Path coefficients are defined as Beta standard rates that are presented in the following table.

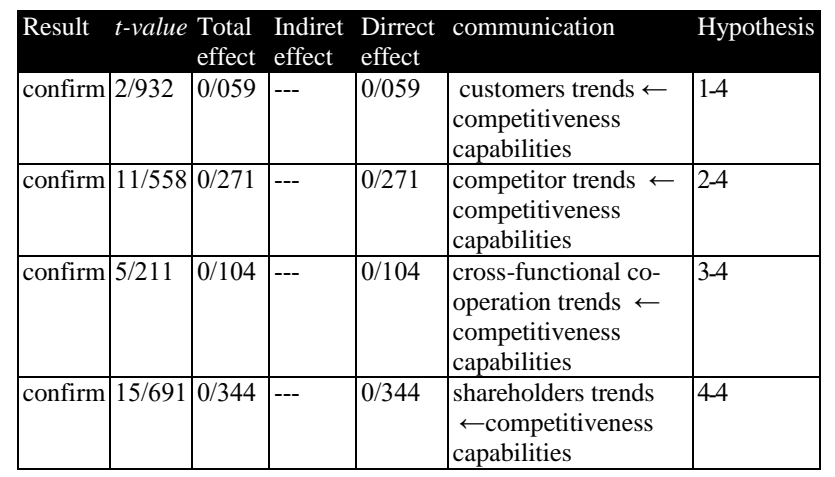

Table $7 \mathrm{t}$-value and path coefficients of the structural path model for the fourth sub hypothesis
As you can see the strategic orientation components such as customers trends, competitor trends and cross-functional cooperation trends and shareholders trends have positive and significant effect on the competitiveness capabilities. Since, t-value for the forth sub hypothesis is bigger than the supposed value of 1/96 in the confidence level of $95 \%$ and error level of 0/05 it is acceptable.

H- Testing the fifth sub hypothesis:

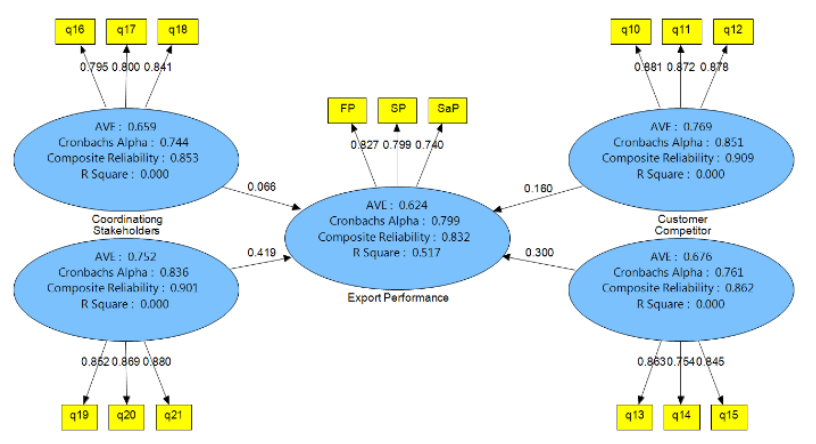

Graph 16 Estimation of path coefficient for the fifth sub hypothesis

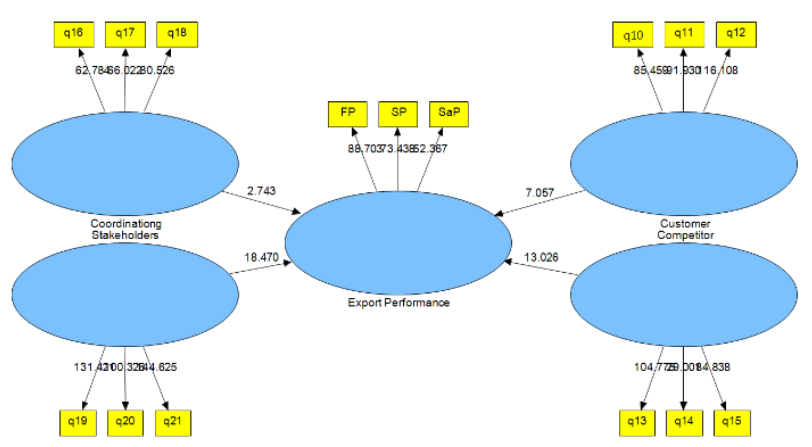

Graph 17 Estimation of t-values of the fifth sub hypotheses of research

Above figure presents the path coefficients and $t$-values between the researcher variables. The path coefficients are defined as Beta standard rates, that are presented in the following table.

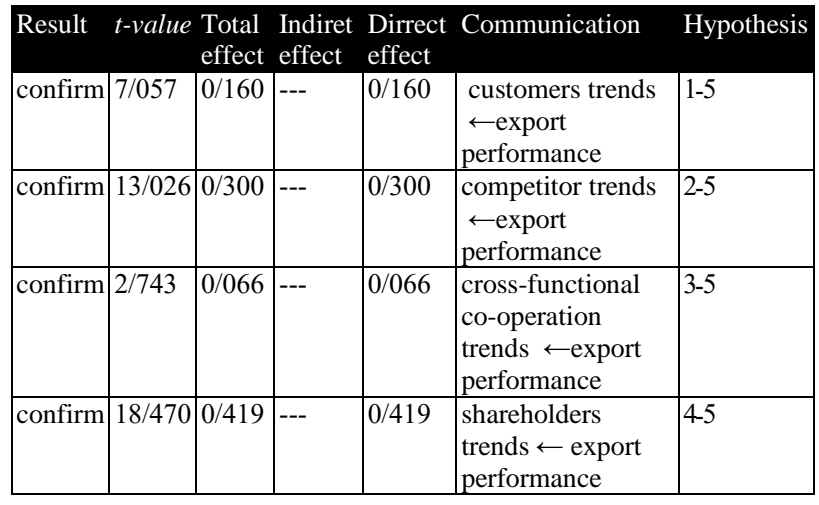

Table 8 t-value and path coefficient of structural path model for the fifth sub hypothesis

ROOSTAEE, Reza, SHIRAZIAN, Zahra and RAHIMI, Mohammad. Investigating the effect of entrepreneurial intensity on creating competitiveness capabilities and export performance. ECORFAN Journal-Mexico. 2019. 
As you can see the competitiveness tap abilities such as customers trends, crossfunctional cooperation trends and significant effect on the export performance. Accordingly any evidence was not observed for rejecting the fifth. Sub hypothesis is bigger than the supposed of $1 / 96$ in the confidence level of $95 \%$ and error level of $5 \%$ it can be acceptable.

I- Testing the sixth sub hypothesis:

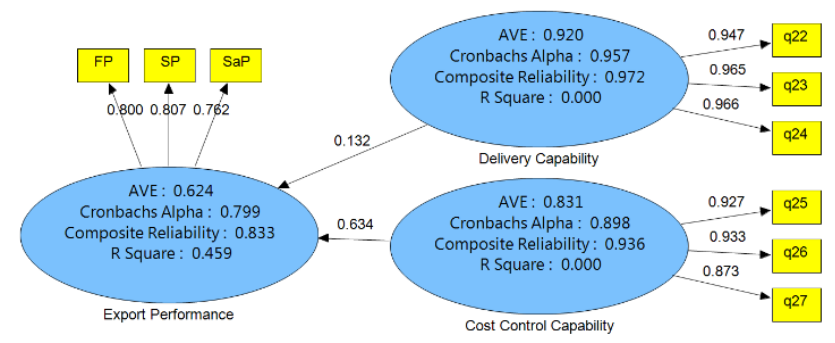

Graph 18 Estimation of the path coefficients for the sixth sub hypothesis

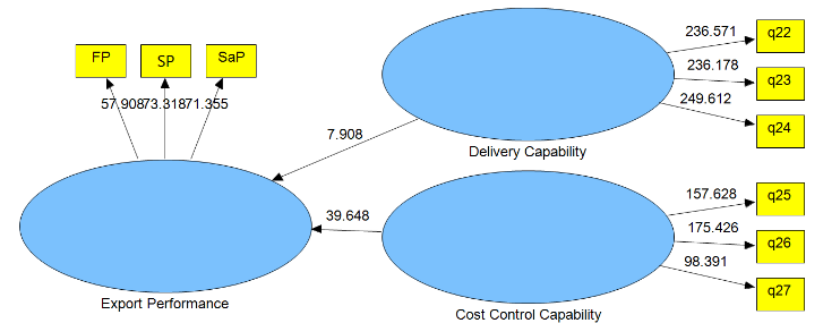

Graph 19 t-values of the sixth sub hypothesis

Above figure presents path coefficients and tvalues between the research variables. Path coefficients are defined as standard rates of Beta that are presented in the following table.

\begin{tabular}{|c|c|c|c|c|c|c|}
\hline Result & t-value & $\begin{array}{l}\text { Total } \\
\text { effect }\end{array}$ & $\begin{array}{l}\text { Indiret } \\
\text { effect }\end{array}$ & $\begin{array}{l}\text { Dirrect } \\
\text { effect }\end{array}$ & communication & Hypothesis \\
\hline confirm & 7/908 & $0 / 132$ & --- & $0 / 132$ & $\begin{array}{c}\text { delivery } \\
\text { capability } \leftarrow \\
\text { export } \\
\text { performance }\end{array}$ & $1-6$ \\
\hline confirm & $39 / 648$ & $0 / 634$ & --- & $0 / 634$ & $\begin{array}{c}\text { cost control } \leftarrow \\
\text { export } \\
\text { performance }\end{array}$ & $2-6$ \\
\hline
\end{tabular}

Table 9 t-value and path coefficients of the structural path model for the sixth sub hypothesis

As you can see the components of the competitiveness capabilities such as delivery capability and the cost control petrochemical are positive and significant effect on the export performance. Accordingly it can be said that there is not any evidence for rejecting the six hypothesis. Since t-value for the supposed value of 1/96 in confidence level of 0/95 and error rate of $0 / 05$ it is acceptable.

\section{Conclusions and Recommendations}

The objective of the present study was investigation of the effect of entrepreneurial intensity and strategic orientation on creating competitiveness capabilities and export performance of Ilam petrochemical company. The obtained results indicate that there entrepreneurial intensity has a significant effect on export performance and the entrepreneurial intensity has a significant effect on the strategic orientation and strategic orientation has a significant effect on the competitiveness capabilities in Ilam petrochemical company.

Considering the obtained results we suggest the attitude of entrepreneurial be improved so that the entrepreneurial intensity be increased. On the other hand the managers should create positive dynamism and motivation to achieve their organization proposes and and should create suitable field for their employees so that they can feel the entrepreneurship process in order to their attitude to entrepreneurship be improved. Also it is suggested that the managers of Ilam petrochemical company present motivation to staff that are employed for entrepreneurship purposes and want to change their conditions and other employees conditions through entrepreneurship process.

Some of these measures include lowinterest loans, motivation of entrepreneur individuals, assignment capital to establish entrepreneurial companies and institutes also top managers of the organization can in their macro policy making for the company can take efforts in creating culture of entrepreneurship. Integration of entrepreneurship culture with organization values and culture creating in the entrepreneurial fields with objective of adjusting the entrepreneurship with staff value system and also encouraging of the staff to entrepreneurship from people who are important for them such as friends, parents and so on have a significant role in entrepreneurial attitude of the staff.

Thus the managers should remove the weaknesses of relationship with customers and strength the customer orientation. Also investigation of the competitors and their weaknesses and strength in strategic orientation effectiveness on the competitiveness capabilities is important. 
The place of the competitors, the changes that they create in customers and their products should be examined constantly, creating a longterm and strategic approach by the managers and also creating some groups for gathering and distributing of data of consumers' needs and competitors measures in a disturbed and competitive environment can help to improving the companies export performance.

Therefore, the organization's managers should provide an environment so that risk taking be popularized. Creating riskfulness mood among the managers of all of the sections will lead to encouraging them toward innovation and they always will try to create new opportunities. Do managers in brainstorm meetings in the company will try to attract innovative ideas in the new Markets. Also with creating customer oriented mood and respecting to clients in a strategical method in marketing area in strategic orientation can improve and promote the export performance.

\section{References}

Azar, A. Gholamzadeh, Ghanavati, M. (2010). Structural path modeling in management, Tehran, Negahe Daneah publications.

Asiaban Rezaei, Mina (2008), investigating the strategic orientation effect on the new product development (evidences of the accepted companies in Tehran stock exchange) unpublished thesis of Tabriz university social and liberal arts department.

Aslanlou, Bahare and Khodami, Soheila (2016) the effect of knowledge inertia and the entrepreneurial intensity on the brand performance, business management view point No. 2- pp45-62.

Akbari, Mohsen, Ebrahim Pourjabari, Mostafa and Houshmand Chaijani, Milad (2015) investigation of the effect of entrepreneurial trend and ambidexterity of innovation on the export performance of new products with decreasing the intensity of product innovation in automotive industry the scientific -research publication of innovation management, fourth years, No. 4-pp81-106.

Anggraeni, E. (2011). Firm s Strategic Orientation in Business Network. Delft University of Technology, 1-27.
Boso, N. (2010), Export EntrepreneuralOriented Behavior and Export Performance, Doctor of Philosophy Dissertation, Loughborough University.

Brower, J. and Rowe, K. (2017), Where the eyes go, the body follows?: Understanding the impact of strategic orientation on corporate social performance, Journal of Business Research, 79, 134-142.

Carvalho C. E., Rossetto C. R.,Verdinelli M. A. (2016) "Strategic orientation as a mediator between environmental dimensions and performance: A study of Brazilian hotels", Journal Of Hospitality Marketing \& Management, 25(7).

Choi M., Yoon H. J. (2016) Training investment and organizational outcomes: A moderated mediation model of employee outcomes and strategic orientation of the HR function", The International Journal Of Human Resource Management, 26(20).

de Lima Rua, O.M.M.M. and Silva França, A.M.S. (2016), Linking Entrepreneurial Orientation to Export Performance, Journal of Entrepreneurship: Research \& Practice, Vol. 2016 (2016), Article ID 169418, DOI: $10.5171 / 2016.169418$

Hakala, H (2011). Strategic Orientations in Management Literature: Three Approaches to Understanding the Interaction between Market, Technology, Entrepreneurial and Learning Orientations. International Journal of Management Reviews, Vol. 13, pp. 199-217.

Johnson J. L., Martin, K. D., Saini, A. (2011) "The role of a firm's strategic orientation dimensions in determining market orientation", Industrial Marketing Management.

Johnson, J., Martin, K., \& Saini, A. (2012). The role of a firm's strategic orientation dimensions in determining market orientation. Industrial Marketing Management, 41, 715-724.

Mu, J Thomas, E. Peng, G. Di Benedetto, A. (2016), Strategic orientation and new product development performance: The role of networking capability and networking ability, Volume 64, 187-201. 
Oura M.M. Zilber, S.N. and Lopes, E.L. (2015), Innovation capacity, international experience and export performance of SMEs in Brazil, International Business Review, In Press.

Perez-Luno, A., Wiklund, J., \& Cabrera, R. (2011). The dual nature of innovative activity: How entrepreneurial orientation influences innovation generation and adoption. Journal of Business Venturing,26(5), 555-571.

Prakash, D. Jain, S. and Chauhan, K. (2015), Entrepreneurial intensity in relation to presence of entrepreneurship development cell: A study of institutes offering professional courses in national capital region Delhi, India, The International Journal of Management Education 13: 95-105.

Ritala P. et al. (2013) "Gone fishing for knowledge? The effect of strategic orientations on the scope of open knowledge search", Baltic Journal of Management, 8(3), pp. 328-348.

Sardana, D. Terziovski, M. and Gupta, N. (2016), The impact of strategic alignment and responsiveness to market on manufacturing firm's performance, Int. J. Production Economics, 177: 131-138.

Simões J. M., Gomes C. F., Yasin M. M. (2016) "Changing role of maintenance in business organisations: Measurement versus strategic orientation", International Journal Of Production Research, 54(11).

Theodosiou, M., Kehagias, J., \& Katsikea, E. (2012). Strategic orientations, marketing capabilities and firm performance: An empirical investigation in the context of frontline managers in service organizations. Industrial Marketing Management 41, 1058-1070.

Hajipour, Bahman, Jafarizadeh, Forooz \& Rahimi, Farajollah (2015). The effect of the strategic orientation and marketing capabilities on the export performance, business management viewpoint, No. 2. Pp 87-105.

Rastegar, Abasali and Shabani, Atefe (2016). The role of export entrepreneurial mediator on export performance, business management viewpoint, No. 27, pp 73-90.
Zarei Matin, Hassan, Jamprazmi, Mona, Yazdani, Hamidreza and Piriyayi, Hanieh Sadat (2010). Investigation of the relationship between the strategic orientation of company with organizational performance using balances scorecard. Business management, second period No. 6, pp. 97-112.

Sedigh, Mansour, Alavimatin, Yaghoob, Bagheri, Davood and Mirzaei, Nasirabad, (2016). Identifying the relationship between the strategic orientation and organizational performance (case study: the companies of automobile pieces production of Azarbayjan Sharghi province), productivity management, No. 37, pp 181-196.

Moshabaki and Khodami, A. A (2010), the role of the export development program in improving the agencies export performance, management improvement, sixth year, No. 3, successive 17pp. 98-135. 